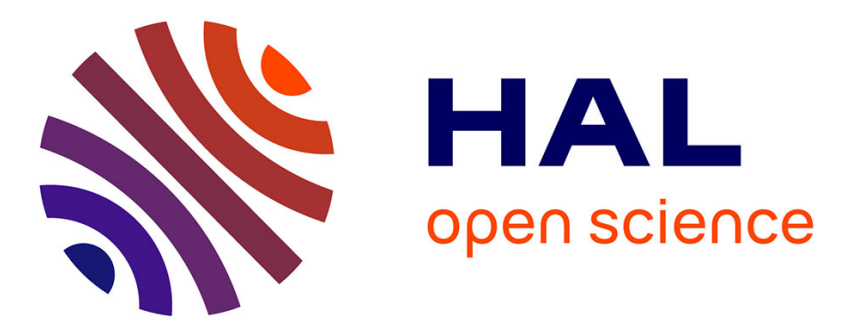

\title{
Treatment of dairy wastewater by electrocoagulation using A-U4G (2017-Al) alloy and pure aluminum as electrode material
}

Adel Aitbara, Assia Khelalfa, Marwa Bendaia, Rahma Abrane, Abdeltif Amrane, Sabir Hazourli

\section{To cite this version:}

Adel Aitbara, Assia Khelalfa, Marwa Bendaia, Rahma Abrane, Abdeltif Amrane, et al.. Treatment of dairy wastewater by electrocoagulation using A-U4G (2017-Al) alloy and pure aluminum as electrode material. Euro-Mediterranean Journal for Environmental Integration, 2021, 6 (1), pp.19. 10.1007/s41207-020-00227-2 . hal-03127426

\section{HAL Id: hal-03127426 \\ https://hal.science/hal-03127426}

Submitted on 22 Feb 2021

HAL is a multi-disciplinary open access archive for the deposit and dissemination of scientific research documents, whether they are published or not. The documents may come from teaching and research institutions in France or abroad, or from public or private research centers.
L'archive ouverte pluridisciplinaire HAL, est destinée au dépôt et à la diffusion de documents scientifiques de niveau recherche, publiés ou non, émanant des établissements d'enseignement et de recherche français ou étrangers, des laboratoires publics ou privés. 


\section{Treatment of Dairy Wastewater by Electrocoagulation Using A-U4G (2017-Al) Alloy and Pure Aluminum as Electrode Material}

\section{Adel Aitbara, Assia Khelalfa Marwa Bendaia, Rahma Abrane, Abdeltif Amrane $\square$ \& $\underline{\text { Sabir Hazourli }}$}

\section{Affiliations}

1. Laboratory of Physical Chemistry of Materials, Department of Chemistry, Faculty of Sciences and Technology, Chadli Bendjedid University, B.P. 36, 36000, El Tarf, Algeria

Adel Aitbara

2. Laboratory of Water Treatment and Valorization of Industrial Wastes, Department of Chemistry, Faculty of Sciences, Badji-Mokhtar University, B.P.12, 23000, Annaba, Algeria

Adel Aitbara, Assia Khelalfa, Marwa Bendaia, Rahma Abrane \& Sabir Hazourli

3. Laboratory of Silicates, Polymères and Nanocomposites (LSPN), 8 Mai 1945 University, B.P 401, 24000, Guelma, Algeria

Assia Khelalfa

4. Univ rennes, Ecole Nationale Supérieure de Chimie de Rennes, CNRS, ISCR - UMR6226, 35000, Rennes, France

Abdeltif Amrane

Corresponding author

Correspondence to Abdeltif Amrane.

\section{Abstract:}

The electrocoagulation (EC) process is an efficient and low-cost system for the purification of wastewater. The aim of this work was to investigate the efficiency of two types of aluminum (Al) electrodes ( $\mathrm{Al}$ alloy and pure $\mathrm{Al}$ electrodes) for the treatment of synthetic semi-skimmed milk wastewater. Turbidity, chemical oxygen demand (COD), and concentration of $\mathrm{Al}$ species were monitored during the experiments. The effect of various parameters, such as current density and type and nature of the electrode were examined. The results showed that $\mathrm{Al}$ alloy electrodes exhibited a higher efficiency than pure Al electrodes. A quasi-total reduction of turbidity and a removal of approximately 58\% of the COD were achieved within 24 min at pH 7 and a current density of 14.3 $\mathrm{mA} \cdot \mathrm{cm}^{-2}$. It was also observed that the removal performance was not affected by the state of the electrode surfaces (polished) under the same operating conditions.

Keywords: Electrocoagulation; Aluminum electrodes; Dairy wastewaters; Alloy and Pure Electrodes. 


\section{Introduction}

The dairy industry, like all agri-food industries, uses a great deal of water for the cleaning and manufacturing of everyday consumer products. However, a significant amount of this water is in the form of wastewater that is not reused and be the source of pollution of the receiving environment (river, sea) (Hazourli et al. 2007). The composition of dairy wastewater depends on the dairy products being processed and their derivatives and, consequently, the production processes implemented. Dairy wastewater commonly contains high concentrations of lactose, proteins, lipids, salts and minerals (Hamdani et al. 2004), resulting in high levels of biochemical oxygen demand, chemical oxygen demand (COD), total suspended solids and total dissolved solids (Hamdani et al. 2004; Tchamango et al. 2010).

Several wastewater treatment processes are used in the dairy industry, including electrochemical treatment (Markou et al. 2017), membrane systems ( Andrade et al. 2014; Aydiner et al. 2014; Bennani et al. 2016; Bortoluzzi et al. 2017; Nagappan et al. 2018), aerobic and anaerobic biological processes (Demirel et al. 2005; Heaven et al. 2011; Yahi et al. 2014; Karadag et al. 2015), coagulation-flocculation (Hamdani et al. 2004; Hazourli et al. 2007), electrocoagulation (EC) and electroflocculation (Şengil et özacar 2006; Aitbara et al. 2016; Benaissa et al. 2016; Melchiors et al. 2016), adsorption (Al-Jabari 2017), EC-electrooxidation coupling (Yavus et al. 2011; TorresSánchez et al. 2014; Aitbara et al. 2017; Chakchouk et al. 2017) and EC-adsorption coupling (Eulmi et al. 2019).

EC is a physico-chemical technique that involves dissolution of metals at the anode accompanied by a simultaneous formation of hydroxyl ions and hydrogen at the cathode (Mameri et al. 2001; Elabbas et al. 2016; Yavus et al. 2018; Changmai et al. 2019). The main factor that determines the performance of this process is the nature of the electrodes (aluminum [Al] or iron [Fe] plates). In the case of Al electrodes, the oxidation at the anode generates $\mathrm{Al}^{3+}$ ions, which hydrate and then react with water to form, as a function of $\mathrm{pH}$, monocomplexes such as $\mathrm{Al}(\mathrm{OH})_{2}{ }^{+}$, polycomplexes $\left[\mathrm{Al}_{2}(\mathrm{OH})_{2}{ }^{4+}\right]$ and amorphous species with very low solubility (Murugananthan et al. 2004). Fe electrodes have been reported to exhibit a higher efficiency than $\mathrm{Al}$ electrodes for the removal of organic pollutants, wherein an Fe electrode can produce 16 different Fe hydr(oxide) active species, such as $\mathrm{FeOH}^{2+}$, $\mathrm{Fe}(\mathrm{OH})_{2}{ }^{+}, \mathrm{Fe}(\mathrm{OH})_{3}, \mathrm{Fe}(\mathrm{OH})_{2}, \mathrm{Fe}(\mathrm{OH})_{4}{ }^{-}, \mathrm{FeO}(\mathrm{OH}), \mathrm{Fe}_{2}(\mathrm{OH})_{2}{ }^{4+}$ and $\mathrm{Fe}_{2}(\mathrm{OH})_{4}{ }^{2+}$, and an Fe electrode has no passivation layer accumulation (McBeath et al. 2020). However, the use of Fe leads to secondary pollution since the process leadis to colored solutions; hence Al electrodes are preferred.

According to Jiang et al. (2002), the monomeric and polymeric species formed ultimately transform into Al hydroxide $[\mathrm{Al}(\mathrm{OH}) 3]$ by complex precipitation kinetics. The latter, when generated in the solution, can 
eliminate pollutants either by surface complexation that chemically binds to the hydrated ion or by electrostatic attraction (Aoudjehane et al. 2010).

EC is often used to treat wastewater in general, including industrial wastewater (Holt et al. 2002; Dolati et al. 2017; Hakizimana et al. 2017; Bilińskaa et al. 2019), natural waters (Liu et al. 2018), waters rich in phosphates (Hashim et al. 2019), waters rich in metallic pollutants (Doggaz et al. 2018), leachates (Dia et al. 2018), municipal wastewater (Nawarkar et al. 2019), among others. The major disadvantage of this technique is the energy requirement. However, a high electrical conductivity of the water to be treated and a small distance between electrodes can reduce the energy consumption of the process (Chen et al. 2002).

The aim of the study reported here was to study the removal of organic matter (COD and turbidity) by the EC process using Al electrodes. The experiments were performed on water samples synthesized with powder milk. The batch tests of EC in closed mode and recirculation allowed us to determine the treatment efficiency with two types of electrodes (pure and alloy). The EC treatment performance was assessed for electrodes with a polished surface and those with an unpolished surface. The purity and surface appearance of the electrodes are important factors in EC due to possible negative effects on the efficiency and cost of the treatment (Mouedhen et al., 2008). It is possible that alloy electrodes in the EC cell are less expensive than pure ones, while compared to polished electrodes, the use of unpolished electrodes leads to the contamination of the wastewater with metallic and slats impurities due to the fast corrosion of the unpolished electrodes (Rudd and Scully 1980).

\section{Mechanism of the EC process using Al electrodes}

The EC treatment approach described here combines three main interrelated processes that work synergistically to eliminate pollutants: electrochemistry, coagulation and hydrodynamics (Torres-Sánchez et al. 2014; Aitbara et al. 2016). The mechanisms of chemical coagulation have been widely studied and include trapping, adsorption, neutralization/destabilization of charges and complexation/precipitation (Aitbara et al. 2013; Sher et al. 2013). The mechanism of EC depends on the chemistry of the aqueous medium, including its conductivity and $\mathrm{pH}$; particle size and concentrations of chemical constituents may also influence the process (Attour et al. 2014).

Electrolytic dissolution of an $\mathrm{Al}$ anode produces monomeric species, such as $\mathrm{Al}^{3+}$ and $\mathrm{Al}(\mathrm{OH})_{2}{ }^{+}$at low $\mathrm{pH}$, which at the appropriate $\mathrm{pH}$ values are transformed into $\mathrm{Al}(\mathrm{OH})_{3}$ and then polymerized to $\mathrm{Al}_{\mathrm{n}}(\mathrm{OH})_{3 \mathrm{n}}$ according to the reactions described in Eqs. 1-8 (Murugananthan et al. 2004; Can et al. 2006):

$$
\mathrm{Al}(\mathrm{s}) \rightarrow \mathrm{Al}^{3+}(\mathrm{aq})+3 \mathrm{e}
$$




$$
\begin{aligned}
& 2 \mathrm{H}_{2} \mathrm{O} \rightarrow 4 \mathrm{H}^{+}+\mathrm{O}_{2}+4 \text { é } \\
& 4 \mathrm{OH}^{-} \rightarrow \mathrm{O}_{2}+2 \mathrm{H}_{2} \mathrm{O}+4 \text { é } \\
& 2 \mathrm{H}^{+}+2 \text { é } \rightarrow \mathrm{H}_{2} \\
& 2 \mathrm{H}_{2} \mathrm{O}+2 \mathrm{é} \rightarrow \mathrm{H}_{2}(\mathrm{~g})+2 \mathrm{OH}^{-} \\
& \mathrm{Al}^{3+}+3 \mathrm{H}_{2} \mathrm{O} \rightarrow \mathrm{Al}(\mathrm{OH})_{3}+3 \mathrm{H}^{+} \\
& \mathrm{n} \mathrm{Al}(\mathrm{OH})_{3} \rightarrow \mathrm{Al}_{\mathrm{n}}(\mathrm{OH})_{3 \mathrm{n}} \\
& 4 \mathrm{Al}+3 \mathrm{O}_{2} \rightarrow 2 \mathrm{Al}_{2} \mathrm{O}_{3}
\end{aligned}
$$

The dissolution of aluminum at the anode is modeled via Faraday’s law as follows:

$$
\mathrm{C}_{\mathrm{Al}}=\frac{\text { M.I.t }}{\text { n.F.V }}
$$

where $\mathrm{C}_{\mathrm{Al}}$ is the theoretical aluminum concentration in the reactor $\left(\mathrm{g} \mathrm{L}^{-1}\right) ; \mathrm{M}_{\mathrm{Al}}$ is the molecular weight of aluminum $\left(27 \mathrm{~g} \mathrm{~mol}^{-1}\right)$; I is the current intensity applied (A); $t_{\text {react }}$ is the mean residence time in the reactor (s); $n$ is the number of electrons involved in the dissolution reaction ( $n=3$ for aluminum); F is the Faraday constant $\left(96,500 \mathrm{C} \mathrm{mol}^{-1}\right)$; and $\mathrm{V}_{\text {react }}$ is the reactor volume (2 $\mathrm{L}$ in the present case).

Despite loss of electrode mass and flotation, cost is the main determining factor when weighing the options for the most suitable wastewater treatment process. In this context, the main operating cost of the EC system is related toenergy consumption which is calculated according to Eq. 10.

$$
\mathrm{E}\left(\mathrm{KWh} \cdot \mathrm{m}^{-3}\right)=\frac{\left(\mathbf{U}_{\mathbf{t}} \cdot \mathbf{I}_{\mathbf{t}} \cdot \mathbf{t}\right)}{\mathbf{V}}
$$

Where $\mathrm{E}$ is energy consumption $\left(\mathrm{kWh} / \mathrm{m}^{3}\right) ; \mathrm{U}_{\mathrm{t}}$ is total electrolysis voltage $(\mathrm{V})$; $\mathrm{I}_{\mathrm{t}}$ is total electrolysis current (A); $t$ is electrolysis time (h); $\mathrm{V}$ is volume at the optimum time of electrolysis $\left(\mathrm{m}^{3}\right)$.

\section{Materials and methods}

\subsection{Dairy sample and electrode materials}

Synthetic dairy samples were prepared by dissolving $5 \mathrm{~g}$ of a commercial milk powder (semi-skimmed) in 2 L of distilled water. The semi-skimmed milk powder comprised 31\% proteins, 45\% carbohydrates (primarily lactose), $14 \%$ lipids, $9 \%$ saturated fatty acids and 1\% mineral salts. In the present study, two types of Al electrodes were used as anode and cathode, namely an Al alloy (duralumin) A-U4G (2017-Al) and "pure” Al electrodes (1050). The composition of the Al electrodes employed is summarized in Table 1.

Table 1- Constituents of the aluminum electrodes. 


\begin{tabular}{|c|c|c|c|}
\hline \multicolumn{2}{|c|}{ Alloy electrode } & \multicolumn{2}{c|}{ Pure electrode } \\
\hline chemical element & Percentage (\%) & chemical element & $\begin{array}{c}\text { Percentage } \\
\text { (\%) }\end{array}$ \\
\hline $\mathrm{Cu}$ & 4 & $\mathrm{Si}$ & 0.25 \\
\hline $\mathrm{Fe}$ & 0,7 & $\mathrm{Fe}$ & 0.4 \\
\hline $\mathrm{Mg}$ & 0,7 & $\mathrm{Cu}$ & 0.05 \\
\hline $\mathrm{Mn}$ & 0,7 & $\mathrm{Ti}$ & 0.05 \\
\hline $\mathrm{Si}$ & 0,5 & $\mathrm{Mn}$ & 0.05 \\
\hline $\mathrm{Zn}$ & 0,25 & $\mathrm{Zn}$ & 0.07 \\
\hline
\end{tabular}

\subsection{Electrochemical reactor}

The experimental setup reactor used is schematically shown in Fig. 1. Experiments were carried out in a discontinuous system with closed recirculation using a peristaltic pump at a flow rate of $300 \mathrm{rpm}$. The EC cell consisted of two identical polymethacrylate halves $\left(20 \times 10 \times 5 \mathrm{~cm}^{3}\right)$. The Al electrode plates $\left(15 \times 7 \times 1.2 \mathrm{~cm}^{3}\right)$ were placed into the reactor, as described previously by Aitbara et al. (2017). A KCl solution of $0.75 \mathrm{~g} \mathrm{~L}^{-1}$ was used as supporting electrolyte. The electrode effective area was $105 \mathrm{~cm}^{2}$. The anode-cathode distance on the EC cell was $2 \mathrm{~cm}$.

The anode and the cathode were connected to a DC power supply (EA-PS 3065-10 B, UK) providing a current density up to $400 \mathrm{~A} \mathrm{~m}^{-2}$. The current was kept at a required value for each experiment. At the beginning of a run, the dairy solution (2 L) was fed into the reactor, following which the $\mathrm{pH}$ was adjusted to a desired value using 0.1 M HCl/NaOH and monitoring by a multi-parameter instrument (Consort C931, Turnhout, Belgium). The EC reaction was timed to start when the DC power supply was switched on. Samples for analyses $(10 \mathrm{~mL})$ were periodically taken from the reactor and then filtered using Whatman filter paper (Whatman plc, Maidstone, UK). After each experiment, the cell was cleaned and the electrodes were rinsed in the diluted $\mathrm{HCl}$ solution in order to remove the salt that had been formed at the anode surface.

The dairy solution treatment was examined by measuring the turbidity and COD. The turbidity was determined using a turbidity meter (model GMBH 2100 N; Phywe Systeme GmbH \& Co. KG, Göttingen, Germany. The COD analysis was conducted by the dichromate method, and subsequent optical density measurements were made on a Hach 2400 spectrophotometer (Hach Co., Loveland, CO, USA). The concentration 
of generated $\mathrm{Al}$ ions was determined by an atomic absorption spectrophotometer (AAS spectrophotometer: thermo scientific iCE 3300, Germany).

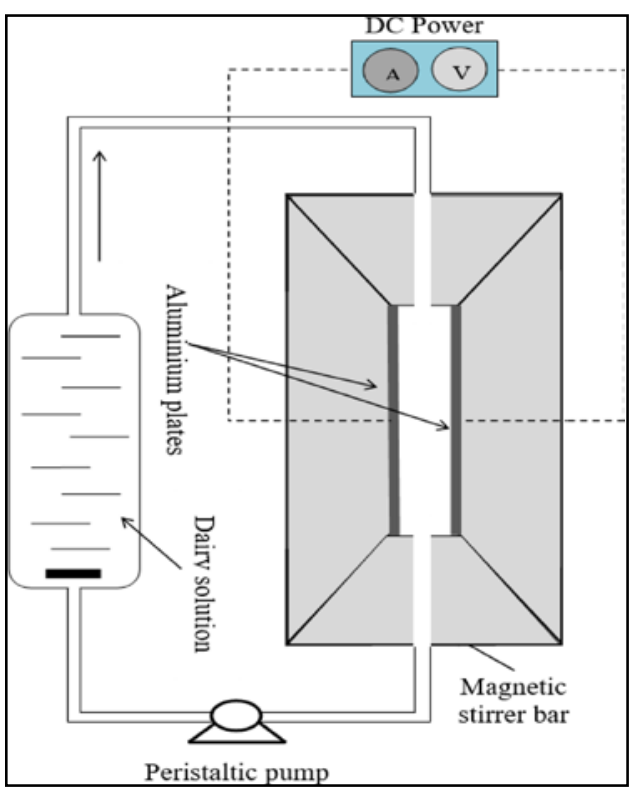

Figure 1- Schematic diagram of the electrocoagulation treatment.

\section{Results and discussion}

\subsection{Effect of the current density on the EC process}

Current density is one of the most important operating parameters that affect the efficiency of the EC process (Kobya et Demirbas 2015; Xu et al. 2017).It can determine the hydroxide formation, the rate and the size of the bubbles produced at the electrodes, the mixing rate within EC and other redox processes (Aitbara et al. 2016; Aitbara et al. 2017; Bayar et al. 2011; Nasrullah et al. 2019).

Holt et al. (2002) have reported that aluminum species are produced rapidly at high current densities, compared to coagulation system. Furthermore, Aitbara et al. (2016) have demonstrated that the density of bubbles increases, while their size decreases with increasing current density, resulting in rapid removal of the aluminum hydroxide from the solution by flotation and a lesser probability of collision between the pollutants and the coagulant. Additionally, the increase in the generation rate of $\mathrm{H}_{2}$ bubbles with the rise of current density is appreciated for the treatment of effluents by flotation (Kobya et al. 2006). 
In preliminary experiments, five values of current densities in the range of 4.8 to $23.8 \mathrm{~mA} . \mathrm{cm}^{-2}$ were applied for both types of electrodes (alloy and pure) at near neutral pH solution. The results are shown in Fig 2 and 3.

The removal performance of the EC process was controlled at different current densities during 60 min of experience. It can be seen that the turbidity decreased over time for the five values of current densities (Figure 2). All applied current densities led to a decrease of turbidity with the fastest kinetics obtained after 24 min with alloy electrode and 28 min with pure electrodes at a current density of $14.3 \mathrm{~mA} . \mathrm{cm}^{-2}$.

As can be seen in Fig. 3, the highest reduction for COD was almost similar for pure and alloy electrodes, about $57 \%$ and 58-59\% obtained for current densities above 4.8 mA.cm ${ }^{-2}$ obtained after nearly 20 min. However, it should be observed that irrespective of the current density applied, faster kinetics were observed using alloy electrodes; this higher efficiency of the alloy Al electrodes should be related to its higher dissolution. The presence of others metal elements facilitates the corrosion of $\mathrm{Al}$ electrode. For example, $\mathrm{Cu}$-containing $\mathrm{Al}$ is known to be more prone to pitting corrosion than pure Al. While, the passive film formed in pure Al inhibits the efficiency of the removal process..

It can be noticed that the EC process is very efficient for lowering turbidity (remove of colloidal and suspended particles) by the formation of $\mathrm{Al}(\mathrm{OH})_{3}, \mathrm{Al}_{n}(\mathrm{OH})_{3 \mathrm{n}}$ and $\mathrm{Al}_{2} \mathrm{O}_{3}$ species. Nevertheless, COD decrease appears hard in the presence of $\mathrm{Al}(\mathrm{OH})_{3}, \mathrm{Al}_{n}(\mathrm{OH})_{3 \mathrm{n}}$ and $\mathrm{Al}_{2} \mathrm{O}_{3}$ species that cannot remove all dissolved particles in solution especially at low concentrations.

At a current density of $14.3 \mathrm{~mA} \cdot \mathrm{cm}^{-2}$, the second step or stationary phase was reached after an electrocoagulation time of 24 min for turbidity and COD with alloy electrodes; while it was observed after 28 min for turbidity and 36 min for COD when the pure electrodes were implemented (Fig. 2 and 3). At this time, despite the continuous production of $\mathrm{Al}^{3+}$, the treatment efficiency was kept constant with reduction rate $\sim 57$ to $60 \%$ for COD and $99 \%$ for turbidity.

In the EC process, whether in the presence of aluminum or iron electrode, the passivation phenomenon is inevitable. In fact, in the presence of dioxygen from the air, the aluminum metal is oxidized to alumina: this oxide forms a protective layer. At the anode of the electrocoagulation cell, the aluminum reacts spontaneously in the presence of dioxygen and water to form an oxide layer of alumina according to the Eq. (11)

$$
2 \mathrm{Al}_{(\mathrm{s})}+3 \mathrm{H}_{2} \mathrm{O}_{(\mathrm{l})} \rightarrow \mathrm{Al}_{2} \mathrm{O}_{3(\mathrm{~s})}+3 \mathrm{H}_{2(\mathrm{~g})}
$$

However, despite the passivation with alumina oxide, the application of a sufficient potential difference releases $\mathrm{Al}^{3+}$ ions in solution, and then, due to the presence of chloride ion (from $\mathrm{KCl}$ ) added to ensure the conduction in the solution to be treated, the corrosion takes place by pitting. Consequently, the chloride ions 
weaken the successive layers of alumina that are more or less porous, leading to the inhibition of passivation (Mechelhoff et al. 2013; Llanos et al. 2014).

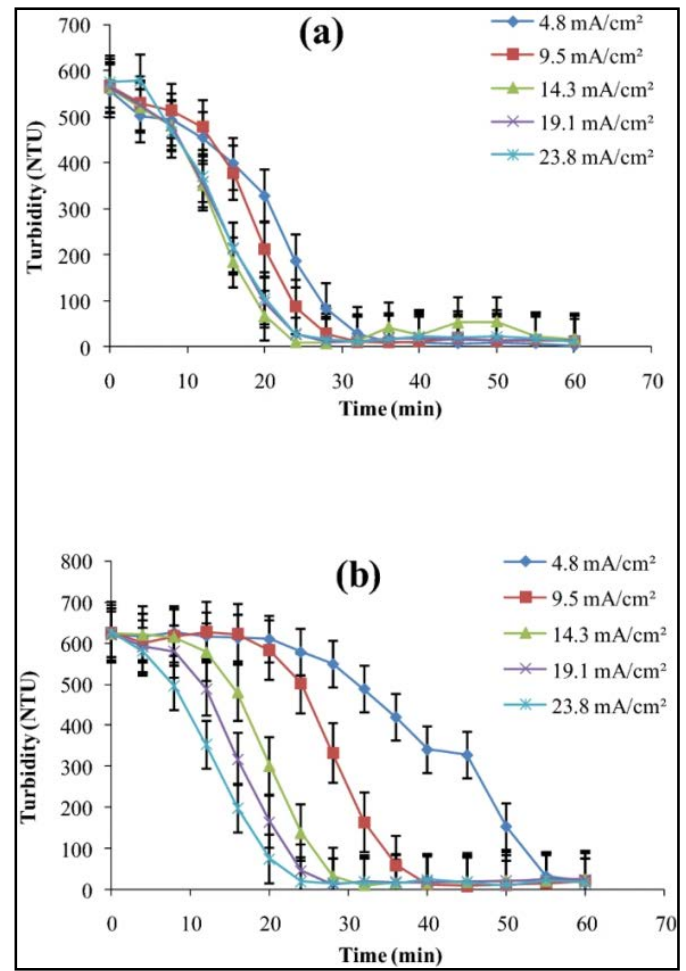

Figure 2- Evolution of turbidity during electrocoagulation (EC) using aluminum (Al) alloy (a) and pure $\mathrm{Al}$ (b) electrodes., Flow rate $=300 \mathrm{rpm}$, temperature $=20^{\circ} \mathrm{C}$, electrodes gap: $2 \mathrm{~cm}$, initial pH: $7.16-7.21$, electrolyte 0.75 g.l l $^{-1} \mathrm{KCl}$ ".

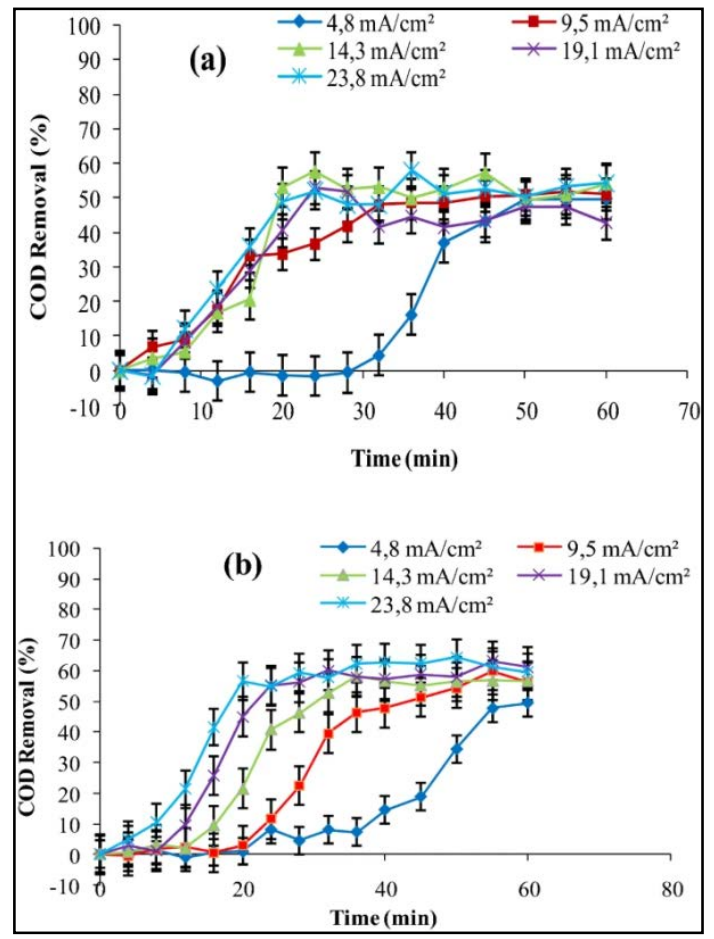

Figure 3- Evolution of chemical oxygen demand (COD) during EC using Al alloy (a) and 
pure $\mathrm{Al}$ (b) electrodes. Flow rate $=300 \mathrm{rpm}$, temperature $=20^{\circ} \mathrm{C}$, electrodes gap: $2 \mathrm{~cm}$, initial pH: $7.16-7.21$, electrolyte 0.75 g.l ${ }^{-1}$ "KCl".

The results of the EC treatment are summarized in Table 2, including variable factors which allowed the determination of the energy consumption at different current densities for both electrodes. It was observed that increasing the currents density stabilized the reduction rate of turbidity in the studied sample. On the other hand, high energies were consumed at current density of $19.1 \mathrm{~mA} \cdot \mathrm{cm}^{-2}$ and $23.8 \mathrm{~mA} \cdot \mathrm{cm}^{-2}$. It appears that a current density of 14.3 mA.cm² wastherefore a good compromise between energy consumption and efficiency for turbidity and COD reduction. Table 2 also confirmed that alloy electrodes are the most appropriate, since leading to a significantly lower energy consumption, for instance 3.18 and $4.17 \mathrm{kWh} . \mathrm{m}^{-3}$ for allow and aluminum electrodes, respectively.

It is important to point out that the current density is directly related to the current intensity and the applied potential. The applied voltage together with the current density can affect directly the dissolution of the anode and the formation of aluminum hydroxides flocs. Therefore, this electrolytic oxidation can cause, according to Equation (6), the release of soluble aluminum, which can form the decantable aluminum hydroxides flocs in the solution. The production of $\mathrm{Al}^{3+}$ species is the key to carry out most of these reactions. The amount of $\mathrm{Al}^{3+}$ species increases usually with the increase of the applied potential, which leads to an efficient treatment of wastewater (Ziati et al. 2018).

The energy calculations which corresponded to the densities tested, show that the energy consumption increases with the increase of the current density due to the polarization of the electrode (Yasakau et al. 2017). (Table 2). In terms of alloy electrodes, it was found that the maximum values reached at the optimum treatment times were $11.593 \mathrm{KWh} . \mathrm{m}^{-3}$ for the removal of turbidity and $13.125 \mathrm{KWh} . \mathrm{m}^{-3}$ for COD. However, in terms of pure electrodes, the energies consumed for the removal of turbidity and COD were $10.235 \mathrm{kWh} . \mathrm{m}^{-3}$ and $18.467 \mathrm{kWh} . \mathrm{m}^{-}$ ${ }^{3}$, respectively. Based on these experiments, the obtained energy variations indicate that the current density or the potential applied affects significant the treatment efficiency.

Table 2- Energy consumption at the optimal treatment time with different current densities

\begin{tabular}{|c|c|c|c|c|c|c|c|c|c|}
\hline \multirow[b]{2}{*}{$\begin{array}{c}\text { Type of } \\
\text { electrodes }\end{array}$} & \multirow[b]{2}{*}{$\begin{array}{c}\text { Density } \\
\left(\mathrm{mA} / \mathrm{cm}^{2}\right)\end{array}$} & \multirow[b]{2}{*}{$\begin{array}{c}\text { Current } \\
\text { Intensity (A) }\end{array}$} & \multirow[b]{2}{*}{$\begin{array}{c}\text { Potential } \\
\text { (V) }\end{array}$} & \multicolumn{3}{|c|}{ Turbidity } & \multicolumn{3}{|c|}{ COD } \\
\hline & & & & $\begin{array}{l}\text { Optimum } \\
\text { time (min) }\end{array}$ & $\begin{array}{c}\text { Reduction rate } \\
(\%) \\
\end{array}$ & $\begin{array}{c}\text { Energie } \\
\left(\mathrm{KWh}^{-3} \mathbf{m}^{-3}\right.\end{array}$ & $\begin{array}{l}\text { Optimum } \\
\text { time (min) }\end{array}$ & $\begin{array}{c}\text { Reduction } \\
\text { rate (\%) }\end{array}$ & $\begin{array}{c}\text { Energie } \\
\left(\mathrm{KWh}^{\left.-\mathrm{m}^{-3}\right)}\right.\end{array}$ \\
\hline & 4.8 & 0.5 & 4.1 & 40 & 98.46 & 0.676 & 60 & 50.89 & 1.025 \\
\hline & 9.5 & 1.0 & 8.4 & 36 & 98.40 & 2.520 & 45 & 52.66 & 3.150 \\
\hline & 14.3 & 1.5 & 10.6 & 24 & 98.42 & 3.180 & 24 & 57.52 & 3.180 \\
\hline
\end{tabular}




\begin{tabular}{|c|c|c|c|c|c|c|c|c|c|}
\hline \multirow{2}{*}{$\begin{array}{l}\text { Al Alloy } \\
\text { electrodes }\end{array}$} & 19.1 & 2.0 & 13.8 & 28 & 98.05 & 6.348 & 24 & 51.84 & 5.520 \\
\hline & 23.8 & 2.5 & 17.5 & 32 & 98.12 & 11.593 & 36 & 57.91 & 13.125 \\
\hline \multirow{5}{*}{$\begin{array}{c}\text { Pure Al } \\
\text { electrodes }\end{array}$} & 4.8 & 0.5 & 4.2 & 60 & 97.07 & 1.050 & 60 & 49.34 & 1.050 \\
\hline & 9.5 & 1.0 & 8.5 & 45 & 98.70 & 3.187 & 55 & 59.89 & 3.867 \\
\hline & 14.3 & 1.5 & 10.5 & 32 & 98.54 & 4.173 & 36 & 57.86 & 4.725 \\
\hline & 19.1 & 2.0 & 13.8 & 28 & 98.08 & 6.348 & 32 & 59.94 & 7.314 \\
\hline & 23.8 & 2.5 & 17.8 & 28 & 97.61 & 10.235 & 50 & 64.25 & 18.467 \\
\hline
\end{tabular}

\subsection{Varying the $\mathrm{pH}$ and $\mathrm{Al}$ concentration during electrocoagulation process:}

The evolution of $\mathrm{pH}$ during the treatment process was followed for a period of 60 minutes, since it is among the major parameters influencing the effectiveness of treatment by EC.

The results are shown in Table 3. We found that the $\mathrm{pH}$ of the medium at the end of the EC treatment was alkaline, ranging between 6.5 and 9, due to the formation of $\mathrm{Al}(\mathrm{OH})_{3}$ species. The presence of $\mathrm{Al}(\mathrm{OH})_{3}$ species is likely to occur at neutral pH (Mouedhen et al. 2008). The optimal current density is favorable to increases in the $\mathrm{pH}$ due the cathodic reduction (Eq. 5), while it is sufficient for the decantation of the formed flocs. A higher current density may lead to the formation of hydrogen and hydroxyls at the cathode, resulting in the flotation of a portion of the formed flocs (Rebhun and Lurie 1993; Yıldız et al. 2008). This evolution of pH towards alkaline values during the EC process was also observed by Farooq Sher et al. (2020) during the treatment of wastewater using Al and Fe electrodes.

In terms of the $\mathrm{Al}$ formed by anodic dissolution, increases the current density increased the content of soluble $\mathrm{Al}^{3+}$ ions in solution, irregardless of the electrode type. Also the $\mathrm{Al}$ values found did not differ significantly between electrode types. This proportional relationship between current density and the formation of dissolved $\mathrm{Al}$ is firmly based on the Faraday law (Eq. 9).

Table 3- Variations in $\mathrm{pH}$ values and aluminum concentration in water samples during the treatment process.

\begin{tabular}{|c|c|c|c|c|c|}
\cline { 3 - 6 } \multicolumn{2}{c|}{} & \multicolumn{2}{c|}{ Alloy electrodes } & \multicolumn{2}{c|}{ Pure electrodes } \\
\hline \multirow{3}{*}{ Parameter } & $\begin{array}{c}\text { Currents density } \\
\mathrm{mA} / \mathrm{cm}^{2}\end{array}$ & Initial & Final & Initial & Final \\
\hline \multirow{3}{*}{$\mathrm{pH}$} & 4,8 & 7,16 & 8,98 & 7,17 & 9,17 \\
\cline { 2 - 6 } & 9,5 & 7,15 & 9,07 & 7,15 & 9,19 \\
\cline { 2 - 6 } & 14,3 & 7,16 & 9,13 & 7,18 & 9,23 \\
\cline { 2 - 6 } & 19,1 & 7,21 & 9,08 & 7,24 & 9,38 \\
\cline { 2 - 6 } & 23,8 & 7,21 & 9,12 & 7,23 & 9,39 \\
\hline
\end{tabular}




\begin{tabular}{|c|c|c|c|c|c|}
\multirow{4}{*}{$\mathrm{Al}(\mathrm{mg} / \mathrm{L})$} & 4,8 & - & 102,26 & - & 93,08 \\
\cline { 2 - 6 } & 9,5 & - & 190,76 & - & 178,47 \\
\cline { 2 - 6 } & 14,3 & - & 376,25 & - & 341,96 \\
\cline { 2 - 6 } & 19,1 & - & 436,32 & - & 402,78 \\
\cline { 2 - 6 } & 23,8 & - & 502,48 & - & 465,59 \\
\hline
\end{tabular}

\subsection{Effect of the state of the electrode surface on the ECprocess: unpolished and polished electrodes}

In order to assess the treatment efficiency of the EC process, the use of unpolished electrodes was assessed in five consecutive carried out with both the $\mathrm{Al}$ alloy and pure $\mathrm{Al}$ electrodes. The experimental conditions were: current density, $14.3 \mathrm{~mA} . \mathrm{cm}^{-2}$, flow rate $=300 \mathrm{t} / \mathrm{min}$, electrodes gap $=2 \mathrm{~cm}$, electrolyte support $\mathrm{KCl}$ of 0.75 g.L ${ }^{1}$, initial $\mathrm{pH}$ between 7.12 and 7.23 at $20^{\circ} \mathrm{C}$ ).

Variations in turbidity and COD for the water samples treated using both types of electrodes are shown in Figs. 4 and 5. In both cases, the turbidity decreased considerably with increasing EC time in all the five tests (Fig. 4). A total reduction ( 99\%) was observed at 24 and 32 min of reaction time with the $\mathrm{Al}$ alloy and pure $\mathrm{Al}$ electrodes, respectively.

For COD (Fig. 5), the highest reduction values were obtained after 32 and 36 min with the pure $\mathrm{Al}$ and $\mathrm{Al}$ alloy electrodes: approximately 56 and 63\%, respectively. Elabbas et al. (2016) reported that Al alloy electrode are the most effective means to remove COD and chromium from tanning waters. This difference in treatment efficiency between $\mathrm{Al}$ alloy and pure $\mathrm{Al}$ electrodes may be related to the composition of the electrodes, corrosion rate and the kinetics of floc formation during treatment. The electrode passivation phenomenon would also be related to this hypothesis. In addition, the formation of the metal oxide at the anode would be much more accentuated when pure $\mathrm{Al}$ electrode is used compared to the $\mathrm{Al}$ alloy electrode.

The performance of treating wastewater samples by EC was also assessed using polished electrodes. To compare both types of electrodes ( $\mathrm{Al}$ alloy and pure $\mathrm{Al}$ ), all tests were performed under the same operating conditions as described above for unpolished electrodes. The time-course of turbidity and COD for the water samples using the two types of electrodes (pure $\mathrm{Al}$ and $\mathrm{Al}$ alloy) are shown in Figs. 6, 7. There was a similar decrease in turbidity and COD in the five consecutive tests regardless of the electrode used, thereby showing the reusability of the electrodes.

Figure 6 shows that there was a total reduction of turbidity (approx. 99\%) for both the $\mathrm{Al}$ alloy and pure $\mathrm{Al}$ polished electrodes, achieved after 28 and 32 min, respectively. COD removal from the solution reached about 
60\% after 40 min with the $\mathrm{Al}$ alloy polished electrodes and 53\% after 36 min with the pure Al electrodes (Fig. 7), suggesting that polishing of the electrodes does not significantly influence the processing efficiency.

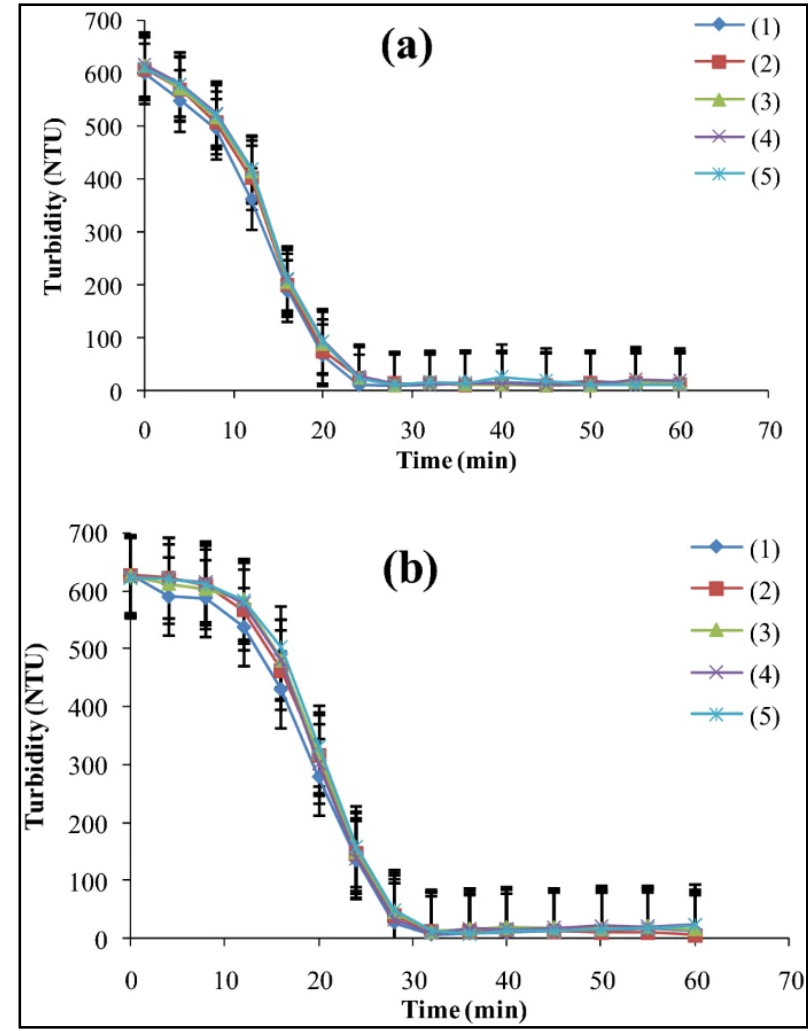

Figure 4- Evolution of turbidity during EC using the $\mathrm{Al}$ alloy (a) and pure $\mathrm{Al}$ (b) electrodes (both unpolished electrodes). Current density $14.3 \mathrm{~mA} / \mathrm{cm}^{2}$, flow rate $=300 \mathrm{t} / \mathrm{min}$, temperature $=20^{\circ} \mathrm{C}$, electrodes gap $=2 \mathrm{~cm}$, initial free $\mathrm{pH}$ between 7.12 and 7.23, electrolyte support $\mathrm{KCl} 0.75$ g.L $\mathrm{L}^{-1}$.

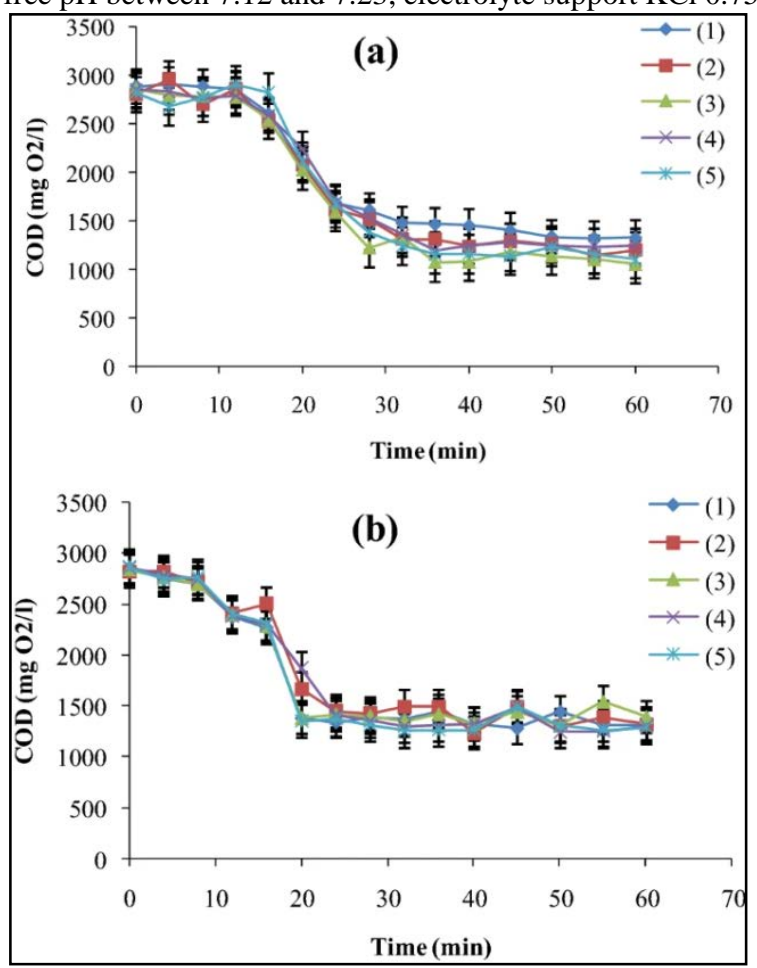


Figure 5- Evolution of chemical oxygen demand (COD) during EC using the $\mathrm{Al}$ alloy (a) and pure $\mathrm{Al}$ (b) electrodes (both unpolished electrodes). Current density $14.3 \mathrm{~mA} / \mathrm{cm}^{2}$, flow rate $=300 \mathrm{t} / \mathrm{min}$, temperature $=20^{\circ} \mathrm{C}$, electrodes gap $=2 \mathrm{~cm}$, initial free $\mathrm{pH}$ between 7.12 and 7.23, electrolyte support $\mathrm{KCl} 0.75$ g.L-1 .

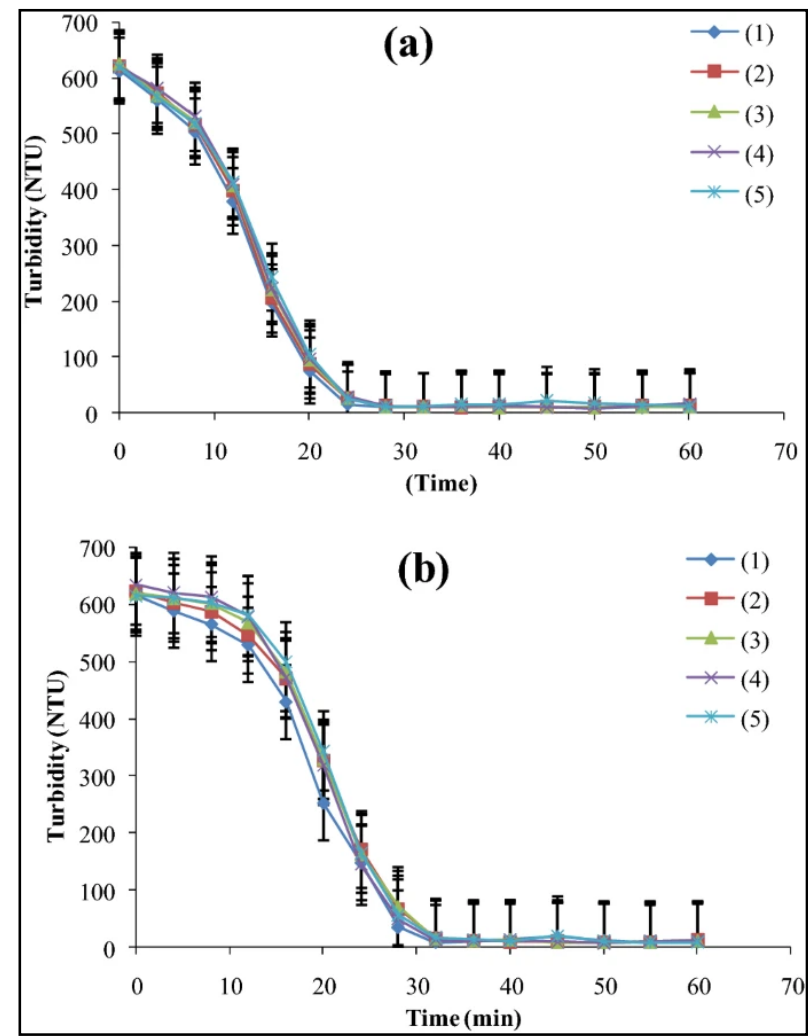

Figure 6- Evolution of turbidity during EC during EC using the $\mathrm{Al}$ alloy (a) and pure $\mathrm{Al}$ (b) electrodes (both unpolished electrodes). Current density $14.3 \mathrm{~mA} / \mathrm{cm}^{2}$, flow rate $=300 \mathrm{t} / \mathrm{min}$, temperature $=20^{\circ} \mathrm{C}$, electrodes gap $=2 \mathrm{~cm}$, initial free $\mathrm{pH}$ between 7.11 and 7.22, electrolyte support $\mathrm{KCl} 0.75$ g. $\mathrm{l}^{-1}$. 


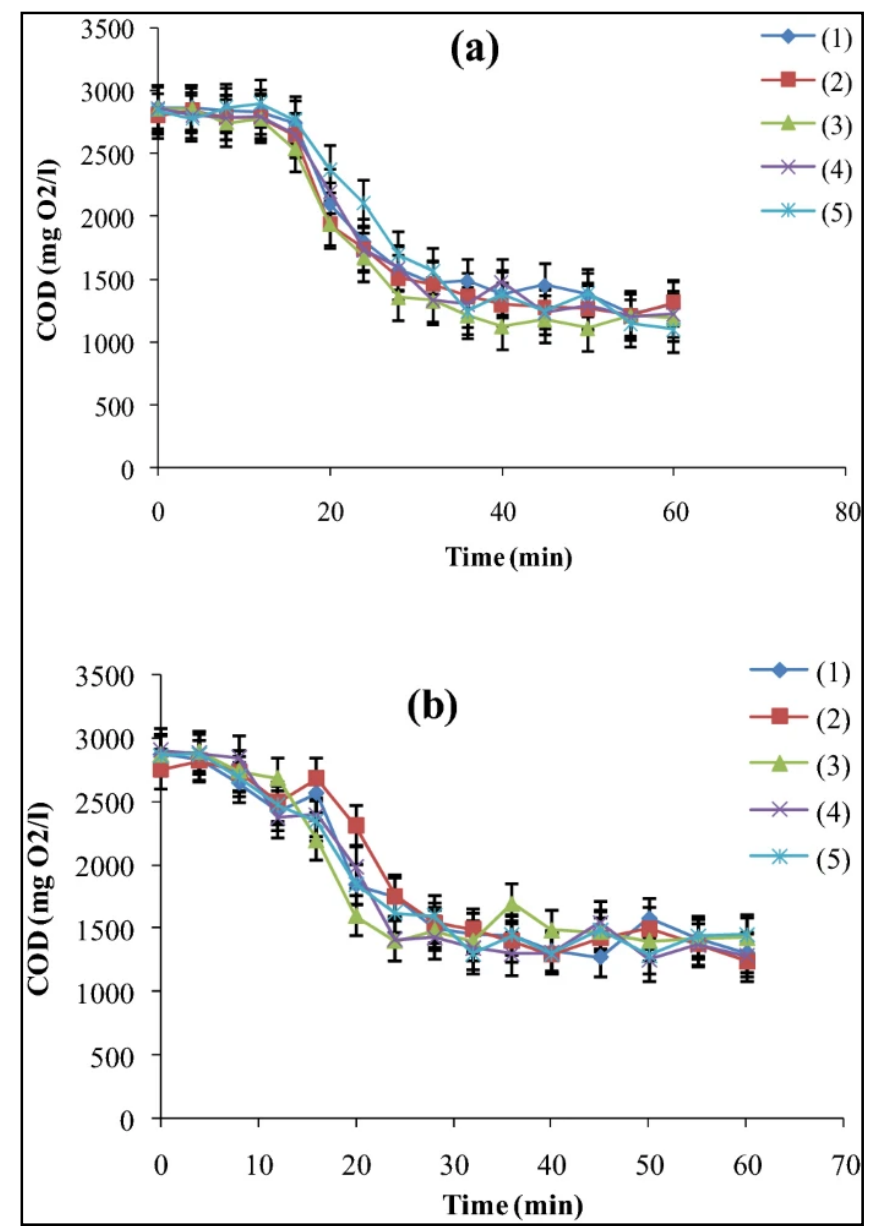

Figure 7- Evolution of COD during EC using the $\mathrm{Al}$ alloy (a) and pure $\mathrm{Al}$ (b) electrodes (both polished electrodes). Current density $14.3 \mathrm{~mA} / \mathrm{cm}^{2}$, flow rate $=300 \mathrm{t} / \mathrm{min}$, temperature $=20^{\circ} \mathrm{C}$, electrodes gap $=2 \mathrm{~cm}$,

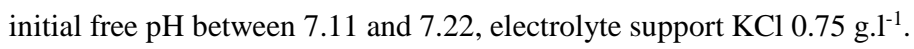

\subsection{Effect of the nature of electrodes on $\mathrm{pH}$ and aluminum concentration}

The effect of the state of the electrodes (unpolished or polished surface) was examined for the $\mathrm{Al}$ alloy and pure $\mathrm{Al}$ electrodes under of the following experimental conditions: initial $\mathrm{pH}$ of 7 , current density of $14.3 \mathrm{~mA} \mathrm{~cm}{ }^{-2}$ and EC time of 60 min. In order to assess the variation of $\mathrm{pH}$ values as well as the amount of $\mathrm{Al}$ released in solution, we performed five consecutive tests on renewed wastewater samples. The results are summarized in Table 4.

For both the $\mathrm{Al}$ alloy and pure $\mathrm{Al}$ electrodes, the variations in $\mathrm{pH}$ showed a similar trend when either unpolished or polished (Table 4), with an increase in $\mathrm{pH}$ in the tests, with the final $\mathrm{pH}$ values falling in the range 8.9-9.3 for both electrode types.

In terms of the dissolution of $\mathrm{Al}$, the amount of $\mathrm{Al}$ decreased after each reuse of the unpolished electrodes, from 380.42 to $348.07 \mathrm{mg} \mathrm{L}^{-1}$ for the $\mathrm{Al}$ alloy electrodes and from 352.05 to $334.95 \mathrm{mg} \mathrm{L}^{-1}$ for the pure $\mathrm{Al}$ 
electrodes. This decrease may be explained by the formation of a protective layer at the surface of the anode, which reduces the corrosion kinetics of the electrodes and the release of the $\mathrm{Al} 3+$ ions in solution that participate in the coagulation phenomenon (Cook 2005). In contrast, the amount of $\mathrm{Al}$ amount after each reuse did not show a clear trend for the polished electrodes (Table 4).

Table 4- $\mathrm{pH}$ values and quantity of aluminium in treated wastewater.

\begin{tabular}{|c|c|c|c|c|c|}
\hline \multirow[b]{2}{*}{ Paramètre } & \multirow[b]{2}{*}{ Test number } & \multicolumn{2}{|c|}{ Alloy electrodes } & \multicolumn{2}{|c|}{ Pure electrodes } \\
\hline & & New & Polished & New & Polished \\
\hline \multirow{5}{*}{$\mathrm{pH}$ final } & 1 & 8,96 & 8,89 & 9,30 & 9,17 \\
\hline & 2 & 9,05 & 9,01 & 9,28 & 9,24 \\
\hline & 3 & 9,09 & 8,96 & 9,31 & 9,16 \\
\hline & 4 & 9,04 & 9,03 & 9,28 & 9,20 \\
\hline & 5 & 9,11 & 9,07 & 9,21 & 9,27 \\
\hline \multirow{5}{*}{$\mathrm{Al}(\mathrm{mg} / \mathrm{L})$} & 1 & 380,42 & 363,29 & 352,05 & 350,08 \\
\hline & 2 & 379,71 & 368,02 & 347,84 & 357,73 \\
\hline & 3 & 372,39 & 357,73 & 340,47 & 342,58 \\
\hline & 4 & 364,85 & 373,66 & 339,62 & 340,61 \\
\hline & 5 & 348,07 & 349,25 & 334,95 & 340,28 \\
\hline
\end{tabular}

\section{Conclusions}

In this study, we investigated the elimination of organic matter from dairy water by the EC process. The results show that the $\mathrm{Al}$ alloy electrode was more efficient than the pure $\mathrm{Al}$ electrode for turbidity and COD removal. Using the $\mathrm{Al}$ alloy electrodes, the reduction in turbidity was quasi-total, while the reduction rate of COD was around 58\% within $24 \mathrm{~min}$ at a current density of $14.3 \mathrm{~mA} \mathrm{~cm}-2$. In addition, the $\mathrm{Al}$ alloy electrodes exhibited a faster reduction kinetics for turbidity and COD compared to that of the pure Al electrodes. On the other hand, the results indicated that the $\mathrm{pH}$ values and the amounts of $\mathrm{Al}$ released in solution varied with EC time during the treatment. The state of the electrode surface (unpolished and polished) did not affect the EC efficiency. These results lead us to conclude that the use of $\mathrm{Al}$ alloy electrodes for wastewater treatment by EC could be an efficient and economical method.

Acknowledgments:The authors acknowledge the financial support of the Ministry of Higher Education and Scientific Research of Algeria.

Conflict of Interest statement: the authors declare that they have no conflict of interest. 


\section{References}

Aitbara A, Hazourli S, Boumaza S, Touahria S, Cherifi M (2013) Etude comparative d'efficacité de prétraitement des effluents d’une laiterie industrielle par coagulation-floculation et électrocoagulation en dynamique. Rev Sci Technol.,Synthèse 26:103-111.

Aitbara A, Cherifi M, Hazourli S, Leclerc J-P (2016) Continuous treatment of industrial dairy effluent by electrocoagulation using aluminum electrodes. Desalin Water Treat 57(8):3395-3404.

Aitbara A, Djellabi R, Eulmi A, Hazourli S (2017) Electrocoagulation and Fenton Hybrid Processes for Dairy Water Purification: In Situ Generation of $\mathrm{H}_{2} \mathrm{O}_{2}$. Sensor Lett 15: 992-997.

Al-Jabari M (2017) Kinetic mass transfer adsorption model for treating dairy wastewater with stone cutting solid waste. Environ Technol Innov 7:21-29.

Andrade LH, Mendes FDS, Espindola JC, Amaral MCS (2014) Nanofiltration as tertiary treatment for the reuse of dairy wastewater treated by membrane bioreactor. Sep Purif Technol 126:21-29.

Aoudjehane M, Rezzouk M, Kellil A, Guigui C (2010) Etude comparative de l'électrocoagulation et de la coagulation floculation vis-à-vis de la modélisation d'une émulsion d’huile de coupe. Revue des sciences de l'eau 23(1):17-30.

Attour A, Touati M, Tlili M, Ben Amor M, Lapicque F, Leclerc J-P (2014). Influence of operating parameters on phosphate removal from water by electrocoagulation using aluminum electrodes. Sep Purif Technol 123:124129.

Aydiner C, Sen U, Topcu S, Ekinci D, Altinay AD, Koseoglu-Imer DY, Keskinler B (2014) Techno-economic viability of innovative membrane systems in water and mass recovery from dairy wastewater. $\mathrm{J}$ Membrane Sci 458:66-75.

Bayar S, Yıldız YŞ, Yılmaz AE, İrdemez Ş (2011) The effect of stirring speed and current density on removal efficiency of poultry slaughterhouse wastewater by electrocoagulation method. Desalination 280(1-3):103107.

Benaissa F, Kermet-Said H, Moulai-Mostefa N (2016) Optimization and kinetic modeling of electrocoagulation treatment of dairy wastewater. Desalin Water Treat 57(13):5988-5994.

Bennani CF, Ousji B, Ennigrou DJ (2016) Reclamation of dairy wastewater using ultrafiltration process. Desalin Water Treat 55(2):297-303.

Bilińskaa L, Blusa K, Gmurekb M, Ledakowicz S (2019) Coupling of electrocoagulation and ozone treatment for textile wastewater reuse. Chem Eng J 358:992-1001. 
Bortoluzzi AC, Faitão JA, Di Luccio M, Dallago RM, Steffens J, Zabot GL, Tres MV (2017) Dairy wastewater treatment using integrated membrane systems. J Environ Chem Eng 5(5):4819-4827.

Can OT, Kobya M, Demirbas E, Bayramoglu M (2006)Treatment of the textile wastewater by combined electrocoagulation. Chemosphere 62(2):181-187.

Chakchouk I, Elloumi N, Belaid C, Mseddi S, Chaari L,Kallel M (2017) A combined electrocoagulationelectrooxidation treatment for dairy wastewater. Brazilian J Chem Eng 34(1):109-117.

Changmai M, Pasawan M, Purkait MK (2019) Treatment of oily wastewater from drilling site using electrocoagulation followed by microfiltration. Sep Purif Technol 210:463-472.

Chen X, Chen G, Yue PL (2002) Investigation on the electrolysis voltage of electrocoagulation. Chem Eng J 57(13):2449-2455

Cook DC (2005) Spectroscopic identification of protective and non-protective corrosion coatings on steel structures in marine environments. Corrosion Sci 47(10):2550-2570.

Demirel B, Yenigun O, Onay TT (2005) Anaerobic treatment of dairy wastewaters: A review. Process Biochem 40(8):2583-2595.

Dia O, Drogui P, Buelna G, Dubé R (2018) Hybrid process, electrocoagulation-biofiltration for landfill leachate treatment. Waste Manage 75:391-399.

Doggaz A, Attour A, Mostefa MLP, Tlili M, Lapicque L (2018) Iron removal from waters by electrocoagulation: Investigations of the various physicochemical phenomena involved. Sep Purif Technol 203:217-225.

Dolati M, Aghapour AA, Khorsandi H, Karimzade S (2017) Boron removal from aqueous solutions by electrocoagulation at low concentrations. J Environ Chem Eng 5(5):5150-5156.

Elabbas S, Ouazzani N, Mandi L, Berrekhis F, Perdicakis M, Pontvianne S, Pons M-N, Lapicque F, Leclerc J-P (2016) Treatment of highly concentrated tannery wastewater using electrocoagulation: Influence of the quality of aluminium used for the electrode. J Hazard Mater 319:69-77.

Eulmi A, Hazourli S, Abrane R, Bendaia M, Aitbara A, Chérifi M, Touahria S (2019) Evaluation of Electrocoagulation and Activated Carbon Adsorption Techniques Used Separately or Coupled to Treat Wastewater from Industrial Dairy. Int J Chem Reactor Eng 17(2):https://doi.org/10.1515/ijcre-2018-0229.

Hakizimana JN, Gourich B, Chafi M, Stiriba Y, Vial C, Drogui P, Naja J (2017) Electrocoagulation process in water treatment: A review of electrocoagulation modeling approaches. Desalination 404:1-21.

Hamdani A, Chennaoui M, Assobhei O, Mountadar M (2004) Caractérisation et traitement par coagulation décantation d’un effluent de laiterie. Lait 84:317-328. 
Hashim K-S, Al Khaddar R, Jasim N, Shaw A, Phipps D, Kot P, Pedrola M-O, Alattabi A-W, Abdulredha M, Alawsh R (2019) Electrocoagulation as a green technology for phosphate removal from river water. Sep Purif Technol 210:135-144.

Hazourli S, Boudiba L, Fedaoui D, Ziati M (2007) Prétraitement par coagulation-floculation d'eaux résiduaires d'une laiterie industrielle. La Société Algérienne de Chimie 17(2):155-172.

Heaven MW, Wild K, Verheyen V, Cruickshank A, Watkins M, Nash D (2011) Seasonal and wastewater stream variation of trace organic compounds in a dairy processing plant aerobic bioreactor. Bioresour Technol 102(17):7727-7736.

Holt PK, Barton GW, Wark M, Mitchell CA (2002) A quantitative comparison between chemical dosing and electrocoagulation. Colloid Surface A 211(2-3):233-248.

Jiang J-Q, Graham N, Andre C, Kelsall GH, Brandon N (2002) Laboratory study of electrocoagulation-flotation for water treatment. Water Res 36(16):4064-4078.

Karadag D, Köroğlu OE, Ozkaya B, Cakmakci M (2015) A review on anaerobic biofilm reactors for the treatment of dairy industry wastewater. Process Biochem 50(2):262-271.

Kobya M, Demirbas E (2015) Evaluations of operating parameters on treatment of can manufacturing wastewater by electrocoagulation. J Water Process Eng 8:64-74.

Kobya M, Demirbas E, Can OT, Bayramoglu M (2006) Treatment of levafix orange textile dye solution by electrocoagulation. J Hazard Mater 132:183-188.

Liu Y, Hu X-M, Zhao Y, Wang J, Lu M-X, Peng F-H, Bao J (2018) Removal of perfluorooctanoic acid in simulated and natural waters with different electrode materials by electrocoagulation. Chemosphere 201:303-309.

Llanos J, Cotillas S, Cañizares P, Rodrigo MA (2014) Effect of bipolar electrode material on the reclamation of urban wastewater by an integrated electrodisinfection/electrocoagulation process. Water Res 53:329-338.

McBeath ST, Mohseni M, Wilkinson DP (2020) Pilot-scale iron electrocoagulation treatment for natural organic matter removal, Environ Technol DOI: 10.1080/09593330.2018.1505965;

Mameri N, Lounici H, Belhocine D, Grib H, Piron DL, Yahiat Y (2001) Defluoridation of Sahara water by small plant electrocoagulation using bipolar aluminum electrodes. Sep Purif Technol 24(1-2):113-119.

Markou V, Kontogianni M-C, Frontistis Z, Tekerlekopoulou AG, KatsaounisA, Vayenas D (2017) Electrochemical treatment of biologically pre-treated dairy wastewater using dimensionally stable anodes. J Environ Manage 202(1):217-224. 
Mechelhoff M, Kelsall GH, Graham NJD (2013) Electrochemical Behaviour of Aluminium in Electrocoagulation Processes. Chem Eng Sci 95:301-312.

Melchiors MS, Piovesan M, Becegato VR, Becegato VA, Tambourgi EB, Paulino AT (2016) Treatment of wastewater from the dairy industry using electroflocculation and solid whey recovery. J Environ Manage 182:574-580.

Mouedhen G. Feki M, De PetrisWery M, Ayedi HF (2008) Behavior of aluminum electrodes in electrocoagulation process. J Hazard Mater 150 (1) (2008) 124-135.

Murugananthan M, BhaskarRaju G, Prabhakar S (2004) Separation of pollutants from tannery effluents by electro flotation. Sepa Purif Technol 40(1):69-75.

Nagappan S, Phinney D, Heldman D (2018) Management of Waste Streams from Dairy Manufacturing Operations Using Membrane Filtration and Dissolved Air Flotation. Applied Sci 8(12):2694.

Nasrullah M, Zularisam AW, Krishnan S, Sakinah M, Singh L, Fen YW (2019) High performance electrocoagulation process in treating palm oil mill effluent using high current intensity application. Chinese J Chem Eng 27(1):208-217.

Nawarkar CJ, Salkar VD (2019) Solar powered Electrocoagulation system for municipal wastewater treatment. Fuel 237:222-226.

Rebhun M, Lurie M (1993) Control of Organic Matter by Coagulation and Floc Separation. WaterSciTechnol 27(11):1-20.

Rudd WJ, Scully JC (1980) The function of the repassivation process in the inhibition of pitting corrosion on aluminium. Corros. Sci. 20 (1980) 611-631.

Şengil IA, özacar M (2006) Treatment of dairy wastewaters by electrocoagulation using mild steel electrodes. J Hazard Mater 137(2):1197-1205.

Sher F, Malik A, Liu H (2013) Industrial polymer effluent treatment by chemical coagulation and flocculation. J Environmental Chemical Engineering 1: 684-689.

Sher F, Hanif K, Iqbal SZ, Imran M (2020) Implications of advanced wastewater treatment: Electrocoagulation and electroflocculation of effluent discharged from a wastewater treatment plant, J Water Process Engineering 33: 101101.

Tchamango S, Nanseu-Njiki Charles P, Ngameni E, Hadjiev D, Darchen A (2010) Treatment of dairy effluents by electrocoagulation using aluminiumelectrodes. Sci Total Environ 408:947-952. 
Torres-Sánchez AL, López-Cervera SJ, Catalina de la Rosa, Maldonado-Vega M, Maldonado-Santoyo M, PeraltaHernández JM (2014) Electrocoagulation process coupled with advanced oxidation techniques to treatment of dairy industry wastewater. Int J Electrochem Sci 9(11):6103-6112.

Xu L, Cao G, Xu X, Liu S, Duan Z, He C, WangY, Huang Q (2017) Simultaneous removal of cadmium, zinc and manganese using electrocoagulation: Influence of operating parameters and electrolyte nature. J Environ Manage 204(1):394-403.

Yahi H, Madi N, Midoune K (2014) Contribution to biological treatment of dairy effluent by sequencing batch reactor (SBR).Desalin Water Treat 52(10-12):2315-2321.

Yasakau K, Zheludkevich ML, Ferreira MGS (2017) Corrosion and corrosion protection of aluminum alloys.reference module in chemistry. Mol Sci Chem Eng 115-127.

Yavuz Y, Ögütveren ÜB (2018) Treatment of industrial estate wastewater by the application of electrocoagulation process using iron electrodes. J Environ Manage 207:151-158.

Yavuz Y, Ocal E, Koparala AS, Ogutverena UB (2011) Treatment of dairy industry wastewater by EC and EF processes using hybrid Fe-Al plate electrodes. J Chem Technol Biotechnol 86(7):964-969.

Yıldız YŞ, Koparal AS, Keskinler B (2008) Effect of initial pH and supporting electrolyte on the treatment of water containing high concentration of humic substances by electrocoagulation. Chem Eng J 138(1-3):6372.

Ziati M, Khemmari F, Aitbara A, Hazourli S (2018). Reduction of turbidity and chromium content of tannery wastewater by electrocoagulation process. Water Environ Res 90(7):598-603. 